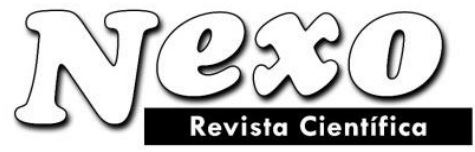

\title{
The modern paradigm of rational environmental use as a trend of environmental legal regulation
}

\section{El paradigma moderno del uso racional ambiental como tendencia de regulación legal ambiental}

\author{
Nadezhda M. Mityakina ${ }^{1 *}$, Lyubov A. Pozharova ${ }^{1}$, Larisa V. Tsurikova ${ }^{1}$, \\ Sergey A. Ivanov ${ }^{2}$, Tatyana I. Kuzmina ${ }^{3}$, Mikhail Yu. Tretyakov ${ }^{1}$ \\ ${ }^{1}$ Belgorod State University, 85 Pobedy Street, Belgorod, 308015, Russia. \\ 2 Tambov State Technical University, 112D Michurinskaya Street, Tambov, 392000, Russia \\ ${ }^{3}$ Plekhanov Russian University of Economics, Stremyanny lane 36, Moscow, 117997, Russia \\ *mityakina@bsu.edu.ru
}

(recibido/received: 15-mayo-2021; aceptado/accepted: 10-agosto-2021)

\begin{abstract}
The main aim of the article is to review modern concepts of the legal principle of rational nature management. To fulfil that aim, a descriptive-analytical and data-gathering methods are utilized. The principle of rational environmental management should be considered as a modern paradigm of environmental and legal regulation. The article substantiates that this paradigm includes doctrinal views on the legal support of rational use of natural resources, state environmental policy, a set of existing legal norms on rational use of natural resources, legal relations on the use of natural resources, and a developed ecological culture. The authors concluded that the central core and an obvious trend in the environmental management paradigm is the idea of the best available technologies.
\end{abstract}

Keywords: rational nature management, natural resource law, nature management, state environmental policy, use of natural resources.

\section{RESUMEN}

El objetivo principal del artículo es revisar los conceptos modernos del principio legal de gestión racional de la naturaleza. Para cumplir con ese objetivo, se utiliza un método descriptivo-analítico y de recolección de datos. El principio de gestión ambiental racional debe considerarse como un paradigma moderno de regulación ambiental y legal. El artículo sustenta que este paradigma incluye visiones doctrinales sobre el sustento legal del uso racional de los recursos naturales, la política ambiental estatal, un conjunto de normas legales existentes sobre el uso racional de los recursos naturales, las relaciones legales sobre el uso de los recursos naturales y un desarrollo 
ecológico. cultura. Los autores concluyeron que el núcleo central y una tendencia obvia en el paradigma de la gestión ambiental es la idea de las mejores tecnologías disponibles.

Palabras clave: manejo racional de la naturaleza, ley de recursos naturales, manejo de la naturaleza, política ambiental estatal, uso de recursos naturales.

\section{INTRODUCTION}

A review of scientific legal ideas about the principle of rational nature management should contribute to the development of a modern concept of nature management and, as a result, the formation of such a system of resource consumption that will ensure their conservation.

Natural objects have always been and are the basis of life and activities of man and mankind. Providing personal and social needs, they fulfill both ecological and economic functions. It is indisputable that the modern stage of civilization development is characterized by an ever increasing use of natural resources and resource consumption, therefore, one of the main environmental challenges today is the need to preserve and reproduce the environment in the interests of the present and future generations. And this is possible only within the framework of the formation of a system of rational sustainable nature management. Law, as one of the main regulators of social relations, is assigned a primary role in the mechanism for the formation of this system and in achieving the main result - preserving the quality and quantity of natural objects.

At the same time, the rational use of natural resources should not and cannot be a local intrastate strategic priority. Ecosystems within state borders are built into the global ecosystem, affect it and experience its influence, therefore, the rationality of nature management should be a paradigm, both for each state and for the entire world community as a whole.

The main scientific approaches to the study of rational nature management as a modern paradigm are systematic and functional approaches. A systematic approach allows us to consider the problem of legal support for rational environmental management as a system, that is, an integral complex of interrelated elements, a set of interacting objects, entities and relations, including: a doctrinal legal basis; government policy; the legal basis itself (that is, a set of legal norms aimed at streamlining relations in the use of natural resources); the process of the impact of these norms on the activities of a natural resource user; the result of this impact, expressed in the satisfaction of a legitimate public interest in preserving the environment and a private interest in achieving economic benefits from the use of a natural object; high level of ecological culture of nature users. The systematic approach allows to form an idea of the system as an integral phenomenon, reveals the hierarchy of its structure, structures its elements.

As you know, the functional approach focuses on clarifying the forms of influence of some social phenomena on others. This makes it possible to learn about the mutual influence of doctrine and legal regulation; legal norms on the rational use of natural resources on each other, their impact on legal relations and law enforcement practice, and the reverse impact of practical activities on the regulatory legal framework; the influence of ecological culture on the behavior of nature users. 
It is well known that trends in legal regulation do not arise in isolation, do not evolve in isolation, by themselves. They stem from the emerging social ideas about socially significant and necessary things, which in turn are concentrated in doctrinal legal concepts.

The role of modern legal science in the practical and applied direction consists, among other things, in the fact that the accumulated legal knowledge and achievements are subsequently transformed into legal norms. Therefore, approaches to legal regulation are based on the modern paradigm.

It is well known that a paradigm is a set of fundamental attitudes, ideas and terms that, over a period of time, provide a community with a model for posing problems and solving them.

\section{MATERIALS AND METHODS}

A descriptive analytical and data-gathering methods are used to satisfy the aim of the study. To do so, the works of legal scholars from different countries were devoted to doctrinal ideas about rational nature management in the context of its legal regulation and related issues in different periods of the development of legal science: Sinden Amy (Sinden, 2014), Guasch J. Juis (Guasch, 2004), Jans Jan H. and Vedder Hans H.B. (Jans et al., 2008), Buxbaum Jeffrey N. and Ortiz Iris N. (Buxbaum et al., 2009), Simila Jukka (Simila, 2002), Meßerschmidt K. (Meßerschmidt, 2011), Onida M. (Onida, 2006), Wendell C. Lawther (Wendell, 2007), Winter G. (Winter, 2004).

The modern legislation of most countries actively and quite energetically uses the term «rational use of natural resources», however, as a rule, there is no legal consolidation of the concept of rational use of natural resources (at least in the legislation of European states). One gets the impression that lawmakers consider this term well-known, generally accepted, well-established and universal, which does not require consolidation, but this is not so. Doctrinal approaches to the concept of rational use of natural resources differ in the context of the history of legal regulation and at present.

In particular, in Soviet law, the term «rational use of natural resources» was understood as such an organization for the use of natural resources that ensures their complete withdrawal and the achievement of the highest economic results (Soloviev, 2008). That is, only economic efficiency was considered in rationality.

At present, views have changed. Rational use of natural resources is considered as complex, economically effective, ensuring the conservation and reproduction of natural resources (Soloviev, 2008).

\section{RESULTS}

Thus, it is clear that at first glance, mutually exclusive interests are embedded in the paradigm of rational nature management: private economic interests and public environmental interests (Mityakina, 2019). In our opinion, modern technological realities are such that they allow these interests not to be opposed, but combined. The higher the need for anthropogenic pressure on natural resources, the more intensive scientific and technological progress in the field of its 
modernization. Thus, using the best available technology, the anthropogenic load is matched to the natural resource potential of the region. According to the Russian definition of the best available technology (BAT), it is a technology for producing products (goods), performing work, providing services, determined on the basis of modern advances in science and technology and the best combination of criteria for achieving environmental protection goals, provided there is a technical feasibility of its application. Therefore, BAT in the process of nature management allows not only not to deplete natural resources, but also to obtain the necessary economic effect (for entrepreneurs - profit).

Modern realities are such that the legal doctrine, referring to the social sciences, cannot develop in isolation from the practical trends occurring in society and the state, just as social and political processes are interconnected with conceptual legal doctrines. Therefore, the modern paradigm of rational environmental management cannot but manifest itself in the directions and trends of state policy, strategic goal-setting, planning, management and forecasting of prospects in this area.

The quintessence of these trends is expressed in state policy in a certain social sphere, in our case, in the field of rational environmental management. State policy, as a rule, is documented through a system of interrelated and interrelated strategic documents.

Without going deeply into the essence of the problem of the ratio of rational nature management and environmental protection, we only note that we consider these two spheres of environmental impact to be correlatively dependent on each other and naturally included in the overall system of ecological activity. Therefore, the vectors of state policy of various states in matters of rational environmental management are covered by policy trends of a higher degree of generalization environmental policy or, say, social policy in general.

In Russia, for example, there is no separate political and legal document on state policy in the field of rational environmental management, and there is no need for it, since this element of state policy is organically included in a single environmental policy. Currently, the Presidential Decree on the foundations of state policy in the field of environmental development of the Russian Federation for the period up to 2030 has been adopted and is in effect. Further development of the Russian legal regulation of rational entrepreneurial nature management is possible only taking into account the provisions of this act, the action plan for its implementation and other documents reflecting the current environmental and economic needs of Russian society.

In the EU, trends and directions for ensuring rational use of natural resources are also reflected in the consolidated strategic document - the Environmental Program for Europe (Sinenko, 2016). As is known, this Program represents the first attempt to formulate long-term environmental policy priorities at the pan-European level, which provide a common framework for improving coordination of national and international efforts to improve the environment throughout Europe and to promote the integration of environmental quality and policy issues. On December 11, 2019, the EU adopted another strategic document, The European Green Deal, which includes a plan to achieve zero total greenhouse gas emissions and zero total environmental pollution by switching from the use of fossil fuels to renewable energy sources and raw materials in the member countries European Union by 2050 (The European Green Deal). 
One of the main modern global trends in ensuring the rational use of natural resources, of course, can be considered the best available technologies. In the European Union, the use of the best available technology has been declared as a general principle that defines the main environmental obligations of the EU member states. The main document regulating this measure is Directive 2010/75 / EU of the European Parliament and of the Council of 24 November 2010 on industrial emissions (integrated pollution prevention and control). This act provides a legal definition of the best available technology and related related terms. Thus, «best available technology» refers to the most efficient and advanced stage in the development of activities and methods of their implementation, which indicates the practical suitability of certain technologies for meeting emission thresholds and other permitting conditions aimed at preventing or, if this is not feasible, to reduce emissions and impact on the environment as a whole. In this case, the concept of «technology» is deciphered; «Affordable technology»; «Best technology». The general conclusion is that the available technologies are the technologies that can be introduced, and the best are the most environmentally efficient technologies. The need for continuous development and implementation of the best available technologies is also stated in Decision No 1386/2013 / EU of the European Parliament and of the Council of 20 November 2013 on a General Union Environment Action Program to 2020 «Living well, within the limits of our planet».

Considering that legal regulation is a targeted impact, its end result is orderly social relations. Consequently, the modern paradigm cannot but include the implementation of the inherent model, in our case it is law enforcement practice in the field of rational environmental management. In each country, permanent analytical work is carried out to monitor the state of the environment, monitor activities to influence natural processes, use natural resources, and implement the goals and objectives of the state environmental policy. This allows us to evaluate promising ideas for the rational exploitation of natural objects are embodied in the system of established stable homogeneous social relations that develop naturally, in accordance with the paradigm. For example, in Russia, the State Report on the State and Protection of the Environment of the Russian Federation is published annually. As part of the analysis report, the impact of individual sectors of the economy on the state of the environment in the Russian Federation is constantly assessed. In particular, in 2019 it was concluded that the mining and energy sectors are characterized by one of the highest levels of impact on the country's ecology. The oil and gas industry in 2019 is characterized by a decrease in the total values of a number of indicators of physical impact on the environment. The nuclear industry in Russia in 2019 accounted for about $9.6 \%$ of the total water withdrawal from natural sources in the territory of the Russian Federation. Compared to 2018, the volume of wastewater discharge has significantly decreased, the total activity increased by $4.4 \%$ (Sinden, 2014).

Waste generation is a major problem in the Russian Federation. So, in 2019, about 7751 million tons of production and consumption wastes were generated, which is 485 million tons higher than in 2018. The overall dynamics of this indicator since 2010 has been characterized by a steady increase. This signals that the paradigm of rational nature management has not yet been implemented in the field of waste generation and disposal. One of the main tools for preventing, limiting and minimizing the negative impact of waste on the environment can be the involvement of secondary resources obtained from potentially useable waste into economic circulation, for which it is necessary to develop a regulatory framework that regulates this area. 
The Russian Federation sees the development of an innovative, energy-efficient «green» economy, the introduction of «green» technologies that contribute to minimizing damage to the environment, ensuring a reasonable balance between the interests of the economy and the preservation of nature and biodiversity as one of the fundamental directions for improving the state of the environment. This area includes such measures as increasing the energy efficiency of enterprises, introducing the principles of sustainable nature management into practice, modernizing the economy taking into account ecosystem services provided by natural ecosystems, as well as including the issue of biodiversity conservation in market mechanisms in the form of payments for ecosystem services. This confirms the thesis that the requirement of rational nature management as the main paradigm of modern environmental activity and environmental legal regulation is recognized not only in science, but also at the state level, within the framework of state and international environmental policy (Turanin et al., 2019).

The paradigm, as a social phenomenon, affects not only the emerging social relations developing within the legal framework, but also the formation of natural resource relations, complicated by a dispute, illegal behavior, the need to apply protection measures, prosecution and similar circumstances. It is the situation with illegal manifestations in the use of natural resources that allows us to present a complete and versatile picture of the possibilities of the concept of environmental and legal regulation, based on the paradigm of rational use of natural resources, reveals the links between legal science, state policy, legal regulation and the phenomena of public life (Turanin et al., 2019).

The analysis of compliance with the requirements of environmental legislation in the implementation of nature management, for example, in Russia is currently disappointing. Although in some areas of environmental management, the number of offenses is decreasing (for example, in the forestry sector in 2019 there were $9 \%$ fewer offenses than in 2018). However, in general, there is an increase in offenses in nature management activities, and many of them are associated with the irrational exploitation of natural resources.

The main powers to supervise compliance with legislation in the Russian Federation are concentrated in the prosecution authorities. In 2019, the Russian prosecutor's office revealed over 280,000 violations of environmental legislation. The results of prosecutorial inspections testify to the widespread prevalence of environmental pollution by business entities, illegal disposal of natural resources and their use, violations by state and local authorities of the procedure for issuing permits, administering payments, non-compliance with legal requirements in the implementation of control and supervisory functions (Turanin et al., 2019).

In addition to general supervisory prosecutorial bodies, a system of environmental state bodies has been created in Russia, designed to identify violations in the field of environmental protection and nature management. The central one is the Federal Service for Supervision of Natural Resources. This service identified 17094 environmental offenses in 2019, which is 2087 more than in 2018. This situation indicates the need not only to promote the paradigm of rational nature management in legislation, but also to form an appropriate ecological culture of users of natural resources (and, first of all, entrepreneurs, whose activities constitute the bulk of the consumption of natural resources). 


\section{CONCLUSION}

Over the course of this study, the modern concepts of the legal principle of rational nature management was investigated. The main users of natural resources (subjects of large and medium-sized businesses), and all natural resource users as a whole, should have such a system of fundamental attitudes and ideas that will form a model of their careful attitude to the environment and rational exploitation of natural resources (Sinenko et al., 2019). As a result, the imperative and dispositive provisions of the legislation on the rational use of natural resources in conjunction with the developed environmental legal consciousness should give an effect in the form of such a system of environmental management, which is based on a reasonable combination of economic benefits and nature conservation.

Modern environmental and legal regulation, both at the domestic and international levels, should be based on the paradigm of rational nature management. This paradigm is a social model of a reasonable combination of economic benefits and environmental preservation in the interests of present and future generations and includes the corresponding doctrinal attitudes; developed ecological culture of nature users; current legal regulations; the result of their implementation (a system of socially desirable practical activities for environmental management, a «green» economy).

\section{CONFLICT OF INTEREST}

The authors confirm that the information provided in the article does not contain a conflict of interest.

\section{ACKNOWLEDGEMENT}

The research was carried out with the financial support of the Ministry of science and higher education of the Russian Federation (agreement №. 075-15-2020-528) using the equipment of the large-scale research facilities, the "BelSU" Botanical Garden of the Belgorod State National Research University.

\section{REFERENCES}

Buxbaum, J. N., \& Ortiz, I. N. (2009). Public sector decision making for public-private partnerships. 391, $123-143$. Transportation Research Board: http://onlinepubs.trb.org/onlinepubs/nchrp/nchrp syn 391.pdf

Decision No 1386/2013/EU of the European Parliament and of the Council of 20 November 2013 on a General Union Environment Action Programme to 2020 «Living well, within the limits of our planet». Official Journal of the European Union N L 354. 28.12.2013. P. 171: http://eur-lex.europa.eu/.

Guasch, J. L. (2004). Granting and renegotiating infrastructure concessions: doing it right. The World Bank.

Jans, J.H., Vedder, H.B. (2008). European Environmental law. 3 ed. Groningen: Europa Law Publishing.

Markhgeym, M. V., Novikova, A. E., Tonkov, E. E., Khlebnikov, A. D., \& Levchenko, V. E. (2018). Land and natural resources in the constitutional subjects of the Eastern European countries and the regional experience of adaptation of the land use in the reform of land relations.

Meßerschmidt, K. (2011). Europäisches Umweltrecht. München, C.H. Beck. 
Mityakina, N. M., Sorokoletova, M. A., Fedoryaschenko, A. S., Gusakova, Y. S., \& Beletskaia, A. A. (2019). International legal regulation of environmental management.

Onida, M. (2006). Products and the Environment. Reflections on 30 Years of EU Environmental Law / Ed. by Prof. Richard. Macrory. Groningen.

Simila, J. (2002). Pollution regulation and its effects on technological innovations. Journal of Environmental Law, 143-160.

Sinden, A. (2014). Cost-Benefit Analysis, Ben Franklin, and the Supreme Court. UC Irvine L. Rev., 4, 1175. Retrieved 2016-07-04

Sinenko, V. S., Turanin, V. Y., Mityakina, N. M., \& Kozyar, N. V. (2016). Tiered approach to the legal regulation of international environmental safety. International Business Management, 10(16), 3338-3340.

Soloviev, N.V. (2008). Comparative legal analysis of the regulation system for the rational use of natural resources in the Russian Federation. Society and Law. No. 2. (in Russian)

The European Green Deal: https://ec.europa.eu/info/strategy/priorities-2019-2024/european-green-deal_en Turanin, V. (2007). Examination of the draft law: new opportunities. Russian justice. 1, 67-69.

Turanin, V. Y., Pozharova, L. A., Kurilenko, N. N., Rumyantsev, M. B., \& Krikun, V. G. (2019). Systematization of legal terms in regional lawmaking. Dilemas Contemporáneos: Educación, Política y Valore, 6(Special).

Turanin, V. Y., Tonkov, E. E., Kuprieva, I. A., Pozharova, L. A., \& Turanina, N. A. (2019). Legal terminology phenomenon in the context of modern legal system evolution.

Wendell, C. Lawther, A. (2007). Privatization of Transportation Systems. Handbook of Transportation Policy and Administration, ed. Jeremy F. Plant, Van R. Johnston and Cristina E. Ciocirlan. Boca Raton, Fla.: CRC Press.

Winter, G. (2004). The Legal Nature of Environmental Principles in International, EC and German Law. Principles of European Environmental Law / Ed. by Prof Richard Macrory. Groningen. 